\title{
Folklore and Conspiracy Theories of a COVID Dissenter: The Life and Sermons of Father Sergii (Romanov)
}

\author{
J. Eugene Clay \\ Arizona State University \\ Tempe, USA
}

\section{Abstract}

The religious studies scholar Bruce Lincoln famously defined myth as "ideology in narrative form" that "naturalizes and legitimizes" social taxonomies. Over two decades, Father Sergii (Romanov), a convicted murderer who turned to religion while in prison, has used myth to shape his public persona, legitimize his spiritual leadership, cultivate the loyalty of his followers, and articulate a vision of holy Russia that seeks to reconcile the Soviet and imperial pasts. Weaving his personal biography into a narrative of national redemption from the sin of regicide, he has helped construct and lead a complex of monasteries. Drawing on a variety of narratives that emphasize Russian exceptionalism, Sergii and his admirers present the cleric as a divinely appointed emissary to lead their nation to spiritual greatness. The conspiracy theories that support this worldview have also encouraged Sergii to denounce both secular and ecclesiastical authorities and to reject public health measures designed to stem the coronavirus pandemic. Despite his revolt against his bishop, Sergii remained in control of his convent until his dramatic arrest on 29 December 2020. This article analyzes some of Sergii's most significant narratives, traces their origins, and weighs their social implications.

\section{Introduction}

The religious studies scholar Bruce Lincoln famously defined myth as "ideology in narrative form" that "naturalizes and legitimizes" social taxonomies [Lincoln 1999: 147]. In the hands of a skillful narrator, such as the notorious "COVID dissident" and excommunicated Russian monk Sergii (Nikolai Vasil'evich Romanov, b. 1955), a myth is not simply a static "pragmatic charter of primitive faith and moral wisdom," as Bronislaw Malinowski argued [Malinowski 1926: 23], but a way to "recalibrate" the sociotaxonomic order "by introducing new categories, eliminating old ones, or revising both categories and the hierarchic orders in which they are organized" [Lincoln 1999: 150]. Myths belong to the small category of narratives which are both credible and authoritative, whose truth is regarded as paradigmatic [Lincoln 2014: 23]. (1) Over two decades, Sergii, a convicted murderer who turned to religion while in prison, has used such narratives to shape his public persona, legitimize his spiritual leadership, cultivate the loyalty of his followers, and articulate a vision of holy Russia that seeks to reconcile the Soviet and imperial pasts. Weaving his personal biography into a narrative of national redemption from the sin of regicide, he has helped construct and lead a complex of monasteries, convents, 
and hermitages in memory of the martyred Emperor Nicholas II. Retelling stories from a variety of sources, Sergii and his admirers present the cleric as a divinely appointed emissary to lead Russia to repentance, rescue it from a global JewishMasonic conspiracy, warn his fellow citizens against the wiles of the imminent Antichrist, and reveal the truth about the pious Christian leader Joseph Stalin, who merely pretended to be an atheist revolutionary in order to make Russia great.

Although President Vladimir Putin and the leadership of the Russian Orthodox Church also embrace a version of Russian exceptionalism, Sergii's extreme views led to conflict in the fraught year 2020. In January, Sergii openly denounced his ecclesiastical superiors and the Russian president; by April, he had condemned public health measures intended to mitigate the coronavirus pandemic. Sergii contended that the epidemic was not real, but simply an excuse to force everyone to be injected with an ersatz vaccine containing microchips that would allow the coming worldwide government to turn all humanity into compliant automatons. From his headquarters in the Convent of the Mother of God, Sporitel'nitsa khlebov [the Grower of Crops], Sergii specifically denounced all of the Russian Orthodox Church's precautions to prevent the spread of the virus and appealed instead to the authority of the spiritual elders on Mount Athos. Although Sergii was defrocked in June and excommunicated in September, he continued to conduct religious services until his dramatic arrest on 29 December 2020, when Russian special forces stormed his convent.

For the most part, Sergii did not invent the grand narratives that he has disseminated and that have informed the construction of his personal biography. Conspiracy theories about the evil intentions of Jews and freemasons, for example, have a long history in Russia. In the early twenty-first century, a lesson plan on masonic conspiracy was even incorporated into a high-school curriculum published in a major educational journal [Abramova and Zaitseva 2003]. By embracing a belief about a nefarious supercomputer in Brussels named "the Beast" that collected personal data on everyone in the world, Sergii unwittingly helped spread a story that conservative American Protestants had invented to promote an evangelistic campaign in 1972. The "Dulles Plan," a secret CIA plot to destroy the USSR and the Russian Federation by undermining the morality of its citizens, originated as an excerpt from a late Soviet novel that came to be widely circulated as an actual project of American intelligence agencies. Similarly, Sergii relied on a fake, but widely distributed, version of Stalin's last will and testament, in which the Soviet dictator confessed his secret Christian faith [Stalin [Trapeznikov] 2004]. Although quite disparate, these various narratives all sounded similar themes: Russian exceptionalism, suspicion of international institutions and norms, the close alignment of Orthodox Christianity and Russian statehood, and the spiritual significance of Russia's great power status. For Sergii, these narratives also offered a way to reconcile the glories of Russia's imperial past and the martyred royal family with the glories of the Stalinist past, with its scientific, military, and industrial achievements - and especially the Soviet victory in World War II. They provided frameworks for developing a compelling personal story, in which Orthodox Christians could participate in national and 
global redemption through their devotion to Russia's great pious rulers, from St. Vladimir (d. 1015) to Stalin. In other words, these narratives elided the contradictions between Soviet Communism and Imperial Russia, while legitimizing and naturalizing a powerful patriarchal state.

Conspiracy theories play an important role in Sergii's construction of reality. Among all the different versions of legend, such theories offer a particularly salient example of "ideology in narrative form." In the 1940s, Karl Popper famously defined the "conspiracy theory of society" as the mistaken view that "whatever happens in society-especially happenings such as war, unemployment, poverty, shortages, which people as a rule dislike - is the result of direct design by some powerful individuals and groups" [Popper 2013 [1945]: 306]. Although Popper admitted that conspiracies existed, he pointed out that they were seldom successful, contrary to the expectations of the adherents of conspirologists. While some scholars have sharply rejected Popper's analysis and the very term "conspiracy theory" as simply a way of dismissing certain types of social critique [Husting and Orr 2007; DeHaven-Smith 2013: 6-11], most have recognized the need for such a category, even as they have struggled to find an adequate definition [Byford 2011: 20-37; Douglas et al. 2017; Uscinski 2018: 5381]. In general, such definitions highlight the importance of a compelling narrative [Fenster 1999: 106] about "malevolent clandestine groups" [Stojanov et al. 2020: 1]. Conspiracy theories ease epistemic crises by providing apparently clear and certain knowledge; they "explain a complex and seemingly random environment through the adoption of a simple model of causality" [Campion-Vincent 2005: 107]. With a distinct set of villains, conspiracy theories are "characterized by their neatness, aligning narrative frameworks from many disparate domains in an efficient and compact manner" [Tangherlini et al. 2020: 61].

By using such legends, Sergii has sought to legitimize his calling as a priest, monk, ascetic elder, and leader of a monastic community. His own personal story and the story of the monasteries that he has helped to create are part of a grander narrative that celebrates both holy imperial Russia and Stalinism, eliminating or ignoring the contradictions between them. The nuns in Sergii's convent are able to sing wartime favorites, such as Isaak Liuban and Pavel Shubin's 1943 "Zastol'naia Volkhovskogo fronta" [Drinking Song of the Volkhov Front], and the Jesus prayer with equal enthusiasm [Luk'ianov 2020 (time stamp 09:14); Srednii put' 2020 (03:50)]. Folding their personal lives into a broader eschatological narrative that identifies a clear group of external evildoers, Sergii and his followers can participate in the redemption of their society without confronting the inherent cognitive dissonance of being an Orthodox Christian Stalinist.

The Making of a Post-Soviet Monk

Born on 19 March 1955 in the village of Kriusha (Gorky (Gor'kovskaia) oblast') in central Russia, Nikolai Vasil'evich Romanov resembles a character in a Dostoevsky novel. Nothing in his early biography hints at his dramatic transformation from a hooligan of the late Soviet period to a charismatic holy 
priest in the early twenty-first century [Skoibeda 2017; Karamzin 2020]. Sergii's admirers note that his given name is strikingly similar to that of the last Russian emperor, Nikolai Aleksandrovich Romanov, assassinated by the Bolsheviks in July 1918 [Aliev 2014 (50:30)]. At the close of the twentieth century, the younger Nikolai Romanov would become a central figure in promoting the cult of the last emperor, helping to build a monastery that commemorated the martyrdom of the royal family.

Like nearly all young men of his age, Romanov served two years of obligatory military service from 1973 to 1975 , rising to the rank of sergeant. After his discharge, he entered the Ministry of Internal Affairs police academy in Omsk, graduated in 1979, married, and worked for a time in law enforcement. By 1984, however, he had divorced his wife, left his profession, and taken up a life of crime [Karamzin 2020]. In April of that year, along with two of his friends, he committed a particularly brutal homicide. Enticing a geography teacher with promises of sex and alcohol, the three murderers drove their victim to a deserted spot, beat him to death, and threw his lifeless body into the Moscow Canal [Skoibeda 2017]. On 25 October 1984, Romanov was arrested on unrelated charges (theft of government property and causing wrongful death in a traffic accident) and in 1985, he was sentenced to four years in a correctional colony. When the authorities learned of his role in a premeditated murder, Romanov underwent a second trial, which extended his sentence to thirteen years.

As a former policeman, Romanov was sent to Correctional Colony 13 (IK13), a special camp for former law-enforcement officers in Nizhnii Tagil (Sverdlov (Sverdlovskaia) oblast'), not far from the site where the Bolsheviks assassinated the last Russian emperor in 1918 [Il'ina 2013; Ostapov 2013, 2014; Skoibeda 2017; Karamzin 2020]. Known as the Krasnaia utka [Red Duck], the camp was notorious for its high-profile prisoners from the security and judicial services. Originally founded in the 1940s, the camp was reformed in 1951 in response to the such'ia voina [bitches' war] that pitted the suki [bitches] criminals who agreed to serve the Soviet state during World War II-against the vory [thieves], who preferred prison to the battlefield [Varese 2001: 165-166; Galeotti 2018: 49-59; Lonsky 2020: 9-13]. The "Red Duck" prison camp became a place where criminals with a past in the security services (bitches) could be separated from the thieves. Its nickname alludes to the underworld argot in which the color red signified strict adherence to all official regulations and the word $u t k a$ (i.e., podsadochnaia utka [decoy duck]), an informant. By contrast, chernyi [black] camps were run according to the criminals' code of honor [Smirnov 2017; Zhadaev 2020].

Life in the Red Duck offered Romanov the opportunity to meet prominent criminals and to develop networks in both the underworld and the security services. During his 13 years of imprisonment, Romanov might well have become acquainted with Leonid Brezhnev's former son-in-law, Iurii Churbanov (19362013), who served as deputy interior minister at the very moment when the future monk was smashing the skull of his hapless victim. Convicted of corruption in 1988, Churbanov spent five years in the Nizhnii Tagil prison until President Boris 
Yeltsin granted him amnesty in 1994. Both men produced fancy ice-cream bowls in the prison factory, and Romanov eventually worked as an electrician repairing the machines that fashioned the bowls. Romanov also might have met Yelstin's friend and colleague General Dmitrii Iakubovskii (b. 1963), who spent four years in the Nizhnii Tagil colony after he was convicted in 1994 of stealing rare books from the Russian National Library in St. Petersburg. Moreover, in 1989, as prison conditions deteriorated in the Soviet Union, the camp commander created a spetsnaz [special forces] team for the Red Duck. During his time in prison, Romanov also met a local vor $v$ zakone [thief with a code of honor, mafia godfather], Temuri Mirzoev (also known as Timur of Sverdlovsk, 1957-2014), a Yazidi Kurd who later converted to Orthodoxy. After he became a priest, Romanov was rumored to be Mirzoev's father confessor. In the years after his release, Romanov has found support both among the Russian mafia and the siloviki [military and law enforcement] [Pushkarev 2015b, 2020; Gulagu.net 2017; Korsakov 2017: 75; Petrov 2018].

During his imprisonment, Romanov developed a religious consciousness, thanks in part to the expanded role of the Russian Orthodox Church among incarcerated prisoners. Throughout most of Soviet history, the Church could not legally engage in any form of social charity, and prisons were off limits to religious organizations. In 1990 new laws guaranteeing freedom of conscience provided greater liberty to the Church, which quickly developed social ministries in hospitals and prisons. In the barracks where Romanov slept, the prisoners were allowed to have an icon corner, and the former policeman turned to Christianity. He helped to build a church dedicated to St. Nicholas that was consecrated at the camp in 1996. Moreover, his good behavior won Romanov the opportunity to work outside the prison. Dire economic conditions in the early 1990s led the camp authorities to sign contracts with local farms and businesses; the camp provided their inmates as a source of cheap labor. As a part of this brigade, Romanov enjoyed considerably greater freedom during the final years of his sentence. Inmates in the work detail had the right to wear civilian clothes and keep some cash. Romanov led a team that renovated a school, a church, and a sports complex in the nearby village of Krasnopol'e. According to one account, Romanov made good use of his relative freedom and fathered a daughter with his third wife in 1993, while he was still formally completing his prison term [Karamzin 2020].

On 21 July 1997, Romanov was released early from his sentence, and he sought to fulfill his religious vocation. Initially, in 1998-1999, he became a riasofor [novice] at the newly created Monastery of the New Martyrs in the village of Alapaevsk, a pilgrimage site where several members of the imperial house of Romanov (including Empress Alexandra's sister, Elizaveta) had been killed in May 1918. He remained in the monastery for about 18 months but came into serious conflict with the abbot and founder of the monastery, Father Moisei (Ianis Laimstarovich Pilats, b. 1970) [E1.ru 2020; Pushkarev 2020]. Having failed in his first efforts at the monastic life, Romanov moved to Ekaterinburg. At the time, the diocese of Ekaterinburg was in turmoil, and its leader, Bishop Nikon (Oleg Vasil'evich Mironov, b. 1960), suffered attacks from both right and left. From the 
right, a group of Orthodox monks and laity accused Nikon of both engaging in homosexual acts and of protecting and promoting closeted gay clergy. On the left, liberals charged Nikon with burning the books of Aleksandr Men' (1935-1990), a reforming priest and theologian of the late Soviet era who was mysteriously murdered at the end of the Soviet period [Gordon 1999]. Although an ecclesiastical commission cleared Nikon of both charges, he was dismissed in 1999 for his failure to keep peace in the diocese and was replaced by an older and more practical administrator, Archbishop Vikentii (Viktor Aleksandrovich Morar', b. 1953) [Sinod 1999].

For a time, Romanov found a true partner and patron in Vikentii. During the decade of his reign over the Ekaterinburg diocese, Vikentii engaged in a vigorous program of church construction. With the archbishop's approval, Romanov became a monk, took the name Sergii, and set to work building a monastery in Ganina Iama [Ganya's Pit], the site where Bolshevik executioners disposed of the royal family's remains in 1918. Already a place of pilgrimage in the 1990s, Ganina Iama became even more venerated after the Russian Orthodox Church canonized Nicholas II, his wife, and his five children in August 2000. Using his considerable talents as an organizer and his contacts among the entrepreneurs of the Urals, Sergii found generous sponsors-including the billionaire Andrei Kozitsyn (b. 1960), head of the Ural Metal Mining Companyto support the new monastery. On 23 September, Patriarch Aleksii II (Aleksei Ridiger, 1929-2008) approved the plan to build a monastery, and by 27 December 2000 the first church, dedicated to the royal passion-bearers, was already completed. Soon afterwards, Sergii made a pilgrimage to Mount Athos, the international center of Orthodox monasticism, where Serbian monks presented him with a copy of a wonder-working icon as a gift for the new monastery [Sedmitsa.RU 2010; Martem'ianov 2020]. Ordained as a deacon and then, on 25 December 2001, as a priest, Sergii served as the monastery's namestnik [abbot] [Kolezev 2020].

\section{Initiation Stories}

In retelling the story of his life, Sergii and his followers have connected his biography to a larger narrative about Russia's place in the world as a great power, both militarily and spiritually. In these stories, Sergii often appears as a divinely chosen emissary. For example, in 2001, Sergii told a visiting Orthodox journalist that many years earlier he had met a blessed stranger in Moscow who predicted that he would render a special service to the royal family - a divine prophecy that found its fulfillment when Sergii became abbot of the Ganina Iama monastery [Zhogolev 2009].

Other elements of Sergii's life were also refashioned to highlight his special role in Russian religious history. The fatal automobile accident, for which Sergii was found criminally liable and for which he was first imprisoned in 1984, became a miraculous turning point for the future monk. Although Sergii survived the accident, in the retelling, the other victims who perished are forgotten: 
Сестра Мария рассказала, что отец Сергий когда-то давно попал в очень сильное ДТП и даже пережил клиническую смерть. В этот момент он даже видел свое тело со стороны. После этого будущий священнослужитель понял, что его миссия - основать обитель, что он и сделал

[Sister Mariia said that Father Sergii once got into a terrible car accident and was even technically dead. In that moment, he could even see his body from the outside. After this, the future priest understood that his mission was to found a monastery, which he did] [Stoianov 2020].

In another, more elaborate version of this story, the Theotokos herself appeared to him during this moment of crisis to affirm his divine mission:

Якобы еще в 80-е годы, управляя автомобилем, он попал в серьезное ДТП. У Сергия . . . врачи диагностировали клиническую смерть. Однако в морге он пришел в себя. Душу в тело вернула Богородица, с которой Романов встретился на небесах. Она обязала его спасти православную Русь, наделила прозорливостью и вернула к жизни. Однако из-за того, что его пассажир погиб в ДТП, Романова приговорили к длительному сроку наказания

[Allegedly, back in the 1980s, he got into a serious accident while driving. The physicians declared Sergii . . . to be clinically dead. But in the morgue, he regained consciousness. The Mother of God, whom Romanov had met in heaven, returned his soul into his body. She ordered him to save Orthodox Rus', bestowed on him the gift of spiritual insight, and returned him to life. However, because one of his passengers had died, Romanov was sentenced to a long prison term] [Antonenkov 2020; cf. Martem'ianov 2020].

Despite his critics' accusations that he hid his past as a murderer (a crime that should have disqualified him from the priesthood, according to canon law), Sergii himself has claimed that he was always completely honest with his ecclesiastical superiors, who ordained him over his own protestations of unworthiness. In June 2020, when he faced the condemnation of a church court, Sergii admitted his criminal past, but emphasized Aleksii II's prophetic approbation of his spiritual vocation:

36 лет назад я, схиигумен Сергий, преступил Уголовный кодекс, за что получил наказание по законному решению областного суда. Вину признал и раскаялся. Отбывая наказание, по благословению построил храм в честь Святителя Николая на ИТК 13. Написал прошение Святейшему Патриарху Алексию II об освящении храма. Находясь с пастырским визитом в Екатеринбурге, Святейший 
Патриарх Алексий II освятил этот храм. При посещении Ганиной Ямы Святейший Патриарх Алексий II сказал мне в присутствии многих: «Монах, священник, наместник»

[Thirty-six years ago, I, schema-monk Sergii, violated the criminal code, for which I received punishment by the lawful decision of the district court. I admitted my guilt and repented. After serving my prison term, I, with the [bishop's] blessing, built a church dedicated to St. Nicholas in Correctional Colony No. 13. I petitioned the Most Holy Patriarch Aleksii II to consecrate the church. While on a pastoral visit to Ekaterinburg, the Most Holy Patriarch Aleksii II consecrated this church. During his visit to Ganina Iama, the Most Holy Patriarch Aleksii II, in the presence of many people, said to me, "Monk, priest, abbot"] [Shestak 2020].

Sergii likewise recounted his remarkable meeting with Patriarch Aleskii II at the Church of St. Nicholas, the house church of the Tretyakov Gallery in Moscow, where one of Russia's most sacred objects, the Vladimir Icon of the Mother of God, has been located since 1999. (2)

- Рукополагал меня владыка Викентий. Находясь в Москве, в храме Святителя Николая, в Третьяковской галерее, где находится чудотворная икона Божией Матери Владимирская, в это время в храм приезжает Святейший Патриарх Алексий II. Сняли сигнализацию, открыли икону для Святейшего Патриарха Алексия II. Он пригласил приложиться к ней после него и спросил меня: «Где служишь?» Я ответил: «У владыки Викентия в Екатеринбурге». Он спросил: «Вы передали владыке, что я благословил вам наградной крест?» Я ответил: «Да, сказал владыке Викентию». Святейший Патриарх Алексий II сказал: «Передайте Владыке Викентию, что я дважды не повторяю»

[While I was in Moscow, in the Church of St. Nicholas, in the Tretyakov Gallery, where the wonderworking icon of the Vladimir Theotokos is located, the Most Holy Patriarch Aleksii II entered. They turned off the alarm and took out the icon for the Most Holy Patriarch Aleksii II. After kissing the icon, he invited me to do the same, and he asked me, "Where are you serving?" I answered, "Under Bishop Vikentii in Ekaterinburg." He asked, "Did you tell your bishop that I wish for him to award you an honorary cross?" I answered, "Yes, I told Bishop Vikentii." The Most Holy Patriarch Aleksii II said, "Tell Bishop Vikentii that I will not repeat myself twice"] [Shestak 2020].

Sergii has claimed a connection with spiritual elders on Mount Athos and with the well-respected Archimandrite Kirill (Ivan Dmitrievich Pavlov, 1919-2017), who served as Patriarch Aleksii's confessor until 2003, when Kirill suffered a stroke 
that left him unable to speak. In an open letter written in July 2020 to Sergii, Metropolitan Kirill (Mikhail Vasil'evich Nakonechnyi, b. 1961) flatly denied Sergii's claims and accused him of deceiving Vikentii and of hiding his criminal past [Kirill 2020]. Sergii's defenders, in turn, have produced their own evidence that his ecclesiastical superiors were fully informed about the nature of his prison sentence long before his ordination to the priesthood in 2001 [66.ru 2020b; Zharkov 2020].

\section{The Sredneural'sk Convent}

Whatever the truth of the matter, Sergii enjoyed a successful clerical career after his release from prison. As early as 2002, while still serving as abbot of Ganina Iama, he helped lay the groundwork to create a convent nearby that would be dedicated to the Icon of the Thetokos, the Grower of Crops. The icon, which portrays the Virgin Mother seated alone on a cloud in the heavens above a field with her arms stretched out in prayer, linked the new convent to a venerable tradition of charismatic spirituality. It was originally commissioned in 1890 by the famous spiritual elder Amvrosii (Aleksandr Mikhailovich Grenkov, 18121891) of the Optina Monastery, who served as the model for Father Zosima in Dostoevsky's novel The Brothers Karamazov. According to one widely circulated origin story, the icon illustrated a vision that Amvrosii had received from the Theotokos [Komova 2006: 213].

The new convent quickly found powerful patrons. In August 2002, the local power station donated a plot of land that had once held German prisoners of war to the church, and the construction of the new monastic complex began. Many volunteers, excited by the prospect of supporting a religious community, sold their property and gave the proceeds for the new project. However, Sergii also put significant pressure on local farmers to donate their land or sell it at a reduced price; by 2005, when the Russian Orthodox Church formally resolved to make the convent an independent community, Sergii used his strategic location to restrict the access of several neighboring farmers to water, roads, and electricity [Sinod 2005; Agenstvo Agrofakt 2005]. Many years of bitter court battles followed, and only in 2019 did the church finally buy out the neighboring landowners [Ostapov 2013; Smirnov 2013; Pushkarev 2015a, 2015b; Pushkarev and Pliusina 2020].

In 2005 Sergii was replaced as abbot of the Ganina Iama monastery and was expelled from the correspondence course of the Moscow Theological Seminary because of his poor academic record [Karamzin 2020; Kirill 2020]. The church still needed his skills as an administrator and fundraiser, and Sergii was appointed father-confessor for the newly independent convent nearby. A year later, with Archbishop Vikentii's blessing, he took the schema, a special vow to lead a more intense ascetic and contemplative life. Traditionally, schema-monks withdraw from all administrative duties. Sergii, by contrast, continued to participate actively in leading and organizing the convent, which established several hermitages deep in the taiga. The convent's relationships with its neighbors did not improve, and Sergii remained a controversial figure. In 2011 Archbishop Vikentii, the bishop 
who had made Sergii's career possible, was transferred to the see of Tashkent, Uzbekistan. With Vikentii's departure, Sergii was removed from the official list of clergy in the Ekaterinburg diocese and added to the clergy of Tashkent - even though he remained physically in Ekaterinburg [Karamzin 2020; Kolezev 2020; 66.ru 2020a].

In the following decade, Sergii achieved greater fame and notoriety, as the convent assumed a more prominent role in Sverdlov (Sverdlovskaia) oblast'. His critics, including the indefatigable Orthodox journalist Raisa Il'ina, uncovered his criminal past and raised questions about the mistreatment of children whom the convent had taken in. In 2013 Il'ina published an open letter to the Sverdlovsk authorities, accusing the priest of abusing his power [Il'ina 2013]. Sergii's aggressive promotion of the cult of the royal family led his critics to accuse him of tsarebozhestvo [deifying the tsar]. However, Church authorities, including the new bishop of Ekaterinburg, defended Sergii and published a documentary about the convent (The Dwelling Place of Faith and Love), which portrayed him as a holy ascetic and practitioner of hesychasm, the discipline of constant prayer [Telestudiia Ekaterinburgskoi eparkhii 2013].

The invasion of Crimea in 2014 opened new avenues for Sergii's public persona. He quickly became a strong supporter of the annexation and ostentatiously traveled to the Ukrainian border to pray for peace. The Orthodox activist and filmmaker Ruslan (Sergii) Aliev completed a second documentary, The Confessor, that celebrated Sergii as a modern-day wise elder, with an especially strong following among the military [Aliev 2014]. His increasing fame brought new admirers to the convent, including the right-wing politician Natal'ia Poklonskaia (b. 1980), who had been appointed the first prosecutor-general of the newly annexed Republic of Crimea [Skoibeda 2017]. Another prominent rightwing figure to embrace Sergii was the retired special forces colonel Vladimir Kvachkov (b. 1948). Known for his strong antisemitic views, Kvachkov was acquitted in 2008 for the attempted assassination of the politician and businessman Anatolii Chubais (b. 1955), one of the architects of Russia's controversial privatization program in the 1990s [Luk'ianov 2020].

\section{Sergii’s Eschatological Kerygma}

Like many Orthodox Christians who have aspired to become spiritual elders, Sergii increasingly emphasized his own charismatic authority over time. By spring 2017, Sergii was performing dramatic rituals of exorcism in his convent, where he identified and battled the demons of modern life, including “компьютерный бес, . . . Интернет, .. Князь тьмы Эйфон, дух чародеев” [the computer demon, the Internet, Prince of Darkness I-phone, spirit of sorcerers] [Lenta.ru 2018 (25:10)]. Sergii dramatically demonstrated his power over the supernatural world by casting out demons from his followers oppressed by them. Like the charismatic Orthodox spiritual elders and other religious virtuosi of prerevolutionary Russia, Sergii exercised this authority over possessed klikushi [shriekers] - primarily women — who traditionally made up part of the entourage 
of a Russian holy man [Worobec 2001]. In spite of his apparent aversion to the Internet, Sergii, aided by young, tech-savvy admirers (such as Vsevolod Moguchev and Ruslan Aliev), created his own YouTube channel to propagate his teachings. Sympathizers, such as the channel Tsarskii krest [Royal Cross], also posted Sergii's messages [Lenta.ru 2018].

Sergii's sermons became increasingly apocalyptic, drawing from scripture, Christian tradition, and contemporary folklore. In a sermon delivered on 3 March 2018, for example, Sergii drew from the canonical book of Revelation, the American myth of a computer called the "Beast in Brussels," and the post-Soviet Russian legend of the "Dulles Plan" to warn his congregation against the coming age of "electronic slavery" [Lenta.ru 2018; JustMedia.ru 2018]. Early in the sermon, Sergii highlighted the fiendish role of the United States in the evolving eschatological saga: the current global decline in morality was initiated by Allen Dulles (1893-1969), the first civilian director of the Central Intelligence Agency, many decades earlier.

Идеолог «холодной войны» Аллен Даллес говорил, что Россию нельзя победить в открытом бою. Ее можно победить только безнравственностью. Он писал: «Будем вырывать духовные корни, уничтожать основы народной нравственности... Главную ставку всегда будем делать на молодежь, станем разлагать, развращать, растлевать ее. Мы сделаем из них циников, пошляков, космополитов». К сожалению, многое из этого уже исполняется на наших глазах. И не только в нашей стране. Более 100 стран в настоящее время живут по законам разврата подобно печально известным городам Содому и Гоморре, т.е. в них узаконены однополые браки, транссексуализм, скотоложство, педофилия. Живут как язычники - «бери от жизни все пока молодой». И даже не задумываются о том, что завтра предстоит встретиться с вечностью, дать ответ пред Богом

[Allen Dulles, the ideologist of the Cold War, said that it was impossible to defeat Russia in an open battle. Russia can only be defeated through immorality. He wrote, "We will tear out the spiritual roots, destroy the foundation of the morality of the people. We will focus always on the young people, whom we will degrade, subvert and corrupt. We will turn them into cynics, perverts, cosmopolitans." Unfortunately, much of this is being fulfilled before our eyes. And not only in our country. More than 100 countries at present live by the laws of depravity like those of the infamous cities of Sodom and Gomorrah. These countries have legalized same-sex marriage, transgenderism, bestiality, pedophilia. They live like pagans: "take everything from life while you are young." And they don't even think that tomorrow they will meet eternity and have to answer God] [Lenta.ru 2018; JustMedia.ru 2018; cf: Ivanov 1976: 49]. 
In this passage, Sergii cites directly from an apocryphal work first attributed to Dulles in a series of nationalist articles and pamphlets published in 1992 and 1993. According to his alleged plan, Dulles recognized that the USSR could be conquered only from within, by corrupting Soviet youth, undermining their morality, and weakening their ability to resist a foreign hegemon. In fact, however, Allen Dulles had no part in the creation of the "Dulles Plan," which is no more than a pastiche of texts from the mouth of a villain in the late Soviet novel Vechnyi zov [The Eternal Call]. Written by the prominent author and publisher Anatolii Stepanovich Ivanov (1928-1999), the novel, which went through three editions and was serialized as a television show, features the anti-hero Arnol'd Mikhailovich Lakhnovskii. A member of the tsarist political police in 1908, Lakhnovskii joins a Trotskyist cell after the revolution in order to commit acts of sabotage. During World War II, he becomes a German officer and reveals how the Nazis intend to derail Communism and make Russia capitalist again. Since its initial publication as a separate manifesto by Allen Dulles, the "Dulles Plan" has often been cited in Russian academic literature as an accurate source for the aims of American intelligence [Il'inskii 2009: 81-82; Golunov and Smirnova 2015: 32; Panchenko 2018: 129-136].

\section{The Beast Computer of Brussels}

As he continued his sermon, Sergii also attacked the increasingly anonymous, globalized financial system that, in his view, threatens to dehumanize the members of his flock, replacing their names with numbers and eliminating any possibility of privacy.

В электронном рабстве у каждого человека вместо имени есть свой номер, как у скотов. То есть ИНН, в котором есть число зверя 666. Если вы даете согласие на обработку персональных данных, вся информация о вас передается во всемирный компьютер, находящийся в Брюсселе. Имя ему - Зверь!

[In the system of electronic slavery, each person has a number-like cattle - instead of a name. That is the T[axpayer's] I[dentifying] $\mathrm{N}$ [umber], which includes the number of the beast - 666. If you agree to have your personal information processed, all the information about you will be sent to a worldwide computer, located in Brussels. Its name is Beast!] [Lenta.ru 2018 (12:45)].

Like many other Orthodox conservatives [Papkova 2011, 120-38], Sergii connected the official Taxpayer's Identifying Number (introduced in the late 1990s to rationalize the Russian tax system) with 666, the number of the evil apocalyptic beast revealed in Revelation 13:18. In warning his flock about the supercomputer in Brussels called "the Beast," Sergii was repeating a story that had originated as part of an American evangelistic campaign by the Pentecostal 
pastor David Wilkerson (1931-2011) in 1973. As part of an advertising campaign to promote his ministry's apocalyptic film, The Rapture [Wilkerson 1972], Wilkerson had created a mock newspaper, The Signs of the Times, filled with fictional stories about the calamities that would take place at the end of the world. One of the articles in the fake tabloid, "The Birth of the Beast," recounted the very story that Sergii referenced nearly four decades later. Located in Brussels, the capital of the "Common Market Confederacy," the supercomputer "would assign each citizen of the world a number - to use for all buying and selling" that would be "invisibly 'laser' tatooed (sic) on the forehead or back of the hand" [Wilkerson 1973: 3; Musser 2011].

Although Wilkerson's story about the Beast was entirely fictional, growing anxieties about the development of a surveillance society made it especially salient in the United States of the 1970s. Rumors about the sinister Brussels supercomputer circulated widely in conservative Protestant publications and in church advertisements in local papers. Wittingly or unwittingly, congregations seeking to increase attendance often repeated elements of Wilkerson's story word for word when advertising their services. For example, on 18 October 1975, Ebenezer Baptist Church of Plymouth, Pennsylvania, ran an ad in the WilkesBarre Times Leader with the headline "How Near the End?" that included the following information:

Writing in the April issue of Gospel Call, published by the Eastern European Mission, Mr. Englund describes a recent unveiling of a three story computer in the Brussels headquarters of the Common Market. As other articles released over the past year have done, Mr. Englund says, "that it has been nicknamed 'The Beast," and is designed to assign each world citizen a number which would be laser tatooed (sic) on the forehead or hand, a walking credit card to be used in all buying and selling [Ebenezer Baptist Church 1975: 10].

As more and more newspapers spread the fictional story, they all seemed to confirm the existence of the Beast Computer. With its citation of "other articles released over the past year," the ad clearly participated in a self-referential flow of information. Very quickly, the news about the Beast in Brussels spread outside of the conservative Protestant communities where it had originated. Rulon Clark Allred (1906-1977), the leader of a polygamous Mormon community, cited the story as proof of the prophecies of his church's founder, Joseph Smith (1805-1844) [Allred, 1982: 115]. The Alabama author Mary Stuart Relfe (1916-2011) incorporated the Beast Computer in her 1981 book When Your Money Fails: The 666 System Is Here, which was swiftly abridged and translated into Russian independently by apocalyptically minded immigrants [Relfe 1981: 15, 42-46]. In 1981 the émigré and radical nationalist Pavel Vaulin (1918-2007), a professor at the University of South Alabama, published a translated section of Relfe's book in his Russian-language journal Niva [Vaulin 1981: 3-6]. By the late 1980s, Russian Baptists and Old Believers had made independent translations of parts of 
Relfe's work, sending the story of the Beast Computer back to the Soviet Union through their international religious networks. In the 1980s in the region of Sverdlovsk, not far from where Nikolai Romanov was serving his sentence for murder, Old Believers were writing extensively about the Beast Computer, drawing upon information published by their co-religionists in Oregon [Soboleva 1997: 211, 217; Ageeva 1997: 11, 16]. The dissolution of the USSR and its Marxist-Leninist worldview encouraged eschatological speculation among Russian Orthodox Christians. By 1991, after the fall of the Soviet Union, the nationalist and monarchist press printed versions of the Beast Computer story that were shared widely [Akhmetova 2011: 146-148; Panchenko 2015: 132-133; 2017: 81-83]. The Orthodox activist and former dissident Vladimir Nikolaevich Osipov (1938-2020) used the same story to attack Russia's new tax identification number system: “Один гигантский компьютер с данными на граждан планеты находится в Брюсселе (он-то и называется 'Зверь' - прямо по Иоанну Богослову!), другой - в Страсбурге" [One gigantic computer with data on the citizens of the planet is located in Brussels (and it is called "the Beast" exactly as John the Theologian prophesied!), and another is in Strasbourg] [Osipov 2000].

Sergii’s Break with Authority: 6 January 2020

Sergii's condemnations of Allen Dulles, American intelligence services, globalist supercomputers, and a dehumanizing financial system did not go beyond the views of many conservative Russian Orthodox Christians. After all, Metropolitan Ioann (Ivan Matveevich Snychev, 1927-1995) of St. Petersburg had been one of the earliest publishers of the Dulles Plan [Panchenko 2015: 125]. Even Sergii's dramatic exorcisms, presented as scandalous in the tabloid press, had precedents. At the venerable Trinity-St. Sergius Lavra, Sergii's colleague, Archimandrite German (Chesnokov) (who died in August 2020, a victim of the pandemic) was famous for driving out demons from the pilgrims who thronged to him. However, at the Christmas Eve service on 6 January 2020 (24 December 2019 in the Julian Calendar followed by the Russian Orthodox Church), Sergii deliberately attacked his secular and his ecclesiastical superiors, President Vladimir Putin and Patriarch Kirill (Vladimir Mikhailovich Gundiaev, b. 1946) of Moscow. Dressed in the white vestments appropriate for the holiday, Sergii greeted the congregation in the packed church with a hearty welcome to the celebration of the vigil for the Feast of the Nativity. Quickly his tone grew darker as he took up several themes illustrating how far Russia had fallen since Joseph Stalin had ruled the country [Sergii 2020].

Sergii began with a reference to the Overton Window, a concept invented by the American sociologist Joseph Overton (1960-2003) that describes the spectrum of acceptability of public policy options. Although the Overton Window was originally intended as a "model for understanding how ideas in society change over time and influence politics" [Mackinac Center 2019], many people now see it as a means to manipulate, rather than measure, public perception. As 
vice-president of the conservative Mackinac Center for Public Policy, Overton believed that his center could contribute to the common good by expanding the range of acceptable policy solutions through a program of public education. Politicians were unlikely to champion policies that had little support, but by bringing new solutions for social problems into civic discourse, Overton hoped to provide a platform to discuss new (especially libertarian) approaches to social questions. Through open discussion of new ideas, the Overton window could be moved or widened to allow for more effective responses to common problems.

Perhaps influenced by the American commentator Glenn Beck (b. 1964), whose 2010 novel The Overton Window featured a secret conspiracy bent on destroying the United States, Russian social scientists have developed a much more sinister vision of the Overton Window as a weapon of mind control. The Overton Window is a technology of persuasion, according to Andrei Gusakov, marketing manager of DataForum LLC, whose article, “Технология, которая вас шокирует, но поможет сдвинуть с места мертвые продажи” [Technology which shocks you, but will help you get dead sales moving] appears in the business journal Kommercheskii Direktor [Commercial Director] [Gusakov 2019: 22]. Likewise, a Russian textbook for prison librarians defines the Overton Window as “технология изменения отношения общества к некогда принципиальным для этого общества вопросам как к совершенно чуждым обществу идеям" [a technology for changing the relationship of a society towards questions that were once of principal importance for that society as well as towards ideas that are completely alien to that society] [Dvorianskov 2018: 14]. Rather than a positive way to expand public discourse, conspiracy theorists also present the Overton Window as a means to manipulate the masses. By using this tool, the argument goes, one can make ideas that once seemed radical into the prevailing norm [Legenda 2020 2020]. For example, some Russians attribute the dramatic transformation of social attitudes toward homosexuality over the last three decades to elites who used the Overton Window to effect that transformation [Baranchik 2014; Skoblikov 2016: 81].

In his Christmas Eve sermon, Sergii suggested that the Overton Window had been used to fool Russians into accepting a fake Putin. The real President Putin, he declared, had long ago been replaced with a double. Such stories about Putin's doubles began circulating soon after he became prime minister in 1999; it was said that Russia's security services employed Putin look-alikes to ensure his safety, a topic of special concern during the brutal Second Chechen War (19992009). In 2000 the leader of the Federal Protection Service of Russia, Evgenii Murov nevertheless dismissed the idea of a Putin double as absurd [Murov 2000]. The rumors continued and became especially important when Putin announced that he would run for a third term in 2012 [Andreev and Novinskii 2016]. For Sergii, proof that Putin has been replaced by his double can be seen in Putin's friendly relations with the Jewish community. Sergii found it shocking that Putin donned the kippah, prayed at the Western Wall, and lit candles in a menorah in a Jewish synagogue. 
Finally, Sergii offered a full-throated defense of Joseph Stalin that, remarkably, reconciled the Georgian dictator with the royal family that he had helped to overthrow. Ignoring Stalin's history of persecuting the Russian Orthodox Church, Sergii read excerpts from the General Secretary's fictional last will and testament, created by the writer Aleksandr Trapeznikov as part of his 1997 novella Завещание красного монарха [The Testament of the Red Monarch], which was also published in the right-wing nationalist newspaper Zavtra [Tomorrow] [Trapeznikov 1997a: 59-60; 1997b]. In his roman à clef, Trapeznikov represented Russian history as a Manichaean struggle between the Judeo-masonic conspiracy and the Russian Order, a secret organization founded in response to the foreign masonic threat. Like the tsars who had preceded him, Stalin was also a member of the order. Although entirely a work of fantasy, the will was republished, without reference to its original source, as an authentic historical document in 2004 in the newspaper Rodnaia Sibir' [Native Siberia] [Stalin [Trapeznikov] 2004], and Sergii cites it as a true expression of Stalin's actual convictions. The dying Stalin claimed that he had never been a revolutionary and that all of his efforts were directed at protecting Russia from the conspiracy of worldwide Zionism. Emphasizing Stalin's rapprochement with the Church in 1943, Sergii portrayed the first General Secretary of the Communist Party as a defender of morality and the true faith.

\section{Sergii and the Pandemic}

Broadcast over the Internet on his YouTube and Telegram channels, Sergii's Christmas Eve sermon marked the beginning of the end of any positive relationship with his ecclesiastical superiors. The pandemic only heightened tensions between the radical monk and the bishops to whom he technically owed obedience. Within a month after Sergii's sermon, on 31 January, two Chinese nationals in Siberia were the first residents of Russia to test positive for the disease [Komarova 2020]. Authorities, both secular and religious, were slow to respond to the crisis. Not until 17 March did Patriarch Kirill of Moscow institute strict hygienic procedures, including continuous disinfection of the spoon for the Eucharist, in order to satisfy state health guidelines and keep the churches open. Even so, these modest steps provoked sharp criticism from conservative churchmen, many of whom denied that the life-giving sacraments could ever spread disease. President Putin did not address the nation about the pandemic until 25 March and then he left the responsibility for taking sanitary measures with local leaders. As some regions instituted lockdowns, Kirill encouraged Orthodox believers to stay home and called on his fellow hierarchs to cooperate with state authorities for the good of all. For some, however, these measures were too late: on 5 April, the Patriarchate announced that several Moscow priests had fallen ill with the virus. On 21 April, the forty-eight-year-old Father Aleksandr Ageikin was the first priest to die from the new disease, a few days after Pascha (Orthodox Easter) [Luchenko 2020]. 
Ageikin's personal tragedy did not silence those who criticized the Patriarch and like-minded bishops who had closed parishes to contain the spread of the virus. Father Sergii was particularly incensed and called on both Kirill and Putin to resign and to hand over all power to him. For his insubordination, church courts banned him from serving as a priest in April, defrocked him in July, and excommunicated him in September. Protected by his supporters, which include right-wing mercenaries, Sergii continued to operate the monastery that he founded and to broadcast his messages via the Internet. However, other more responsible figures in the church also turned to conspiracy theories. On 19 May 2020, the Synod of the Orthodox Church of Moldova, the largest religious body in that country and an autonomous branch of the Russian Orthodox Church, appealed to the Moldovan government to refrain from implementing any program of compulsory vaccination against COVID-19. The appeal, signed by the primate of the Church, Metropolitan Vladimir (Nicolae Cantarean, b. 1952), and all seven of the Church's bishops, cited international legal norms, including Chapter Two, Article 5, of the Oviedo Convention on Human Rights and Biomedicine (1997), which made the patient's “consimțământul liber și în cunoștință de cauză” [free and informed consent] a necessary condition for any medical intervention. At the same time, the bishops also noted several disturbing events that, in their view, fulfilled the biblical book of Revelation and "proorociilor Sfinților Părinţi" [the prophecies of the Holy Fathers] [Orthodox Church of Moldova 2020: 2, 6]. For example, in a speech delivered just a few days earlier on the floor of the Italian parliament, the legislator Sara Cunial (b. 1979) had accused Bill Gates (b. 1955), the American billionaire co-founder of Microsoft, of crimes against humanity. Gates, she claimed, had used vaccines to kill and paralyze children in India and Africa [Parents for Healthcare Rights 2020]. Moreover, many others believed that the future vaccination program against COVID-19 was simply part of Gates's latest evil plan:

Bill Gates este considerat principalul responsabil pentru crearea tehnologiei de microcipare a populaţiei, prin intermediul unui vaccin care să introducă în trup nanoparticule care reacționează la undele transmise de tehnologia $5 \mathrm{G}$ și permit sistemului să îl controleze pe om de la distanţă

[Bill Gates is believed to be primarily responsible for creating technology to microchip the population through a vaccine that introduces nanoparticles into the body that react to waves transmitted by $5 \mathrm{G}$ technology and allow the system to control humans remotely] [Orthodox Church of Moldova 2020: 5].

The bishops suggested that Gates, the Hungarian-born billionaire George Soros, and Israeli Prime Minister Benjamin Netanyahu were all part of the "globalist antichrist system," described long ago by St. John the Theologian in Revelation, the last book of the New Testament. 


\section{Conclusion}

Sergii's rebellion against the church and state took a new turn on 29 December 2020, when special forces invaded the convent, arrested Sergii, and brought him to stand trial on three different charges. First, by refusing to obey his bishop and the church courts, he stands accused of illegally interfering with the activity of a religious organization. Second, for the same reason, he is being brought to account for samoupravstvo [arbitrary rule]. Finally, because he asked his followers in one video sermon, "And are you ready to sacrifice yourself for Russia?" Sergii has been accused of encouraging suicide. Despite his excommunication, Sergii continues to wear his clerical vestments in prison. The circumstances of his sudden arrest (which was quickly followed by the arrest of the dissident Aleksei Naval'nyi (b. 1976) and the mass repression of his movement) have raised concerns among both liberals and conservatives [Novaia gazeta 2021].

Over his 65 years, Sergii has reinvented himself many times. In his first four decades, he took on the roles of soldier, policeman, cold-blooded murderer, and model prisoner. Upon his release from prison in 1997, he has continued to remake himself, drawing on stories, myths, and traditions to fashion a religious trajectory from felon to ascetic saint. Tying his initial vocation to one of the most revered holy objects of both Russian Orthodoxy and Russian nationhood-the Vladimir Mother of God-Sergii continued to seek out tangible symbols of sanctity (especially those connected with the royal Romanov family) that linked him to a sacred Russian past and a divine destiny. His natural gifts as an organizer and his ruthlessness in managing monastic property helped him to build his little Vatican in the Urals, and his ability to weave together powerful folkloric narratives and broadcast them across the world was crucial for building a nationwide following. In the end, however, Sergii was unable to bridge the deep contradictions in the narratives that he told and the life that he lived. While casting out computer demons named "I-phone," Sergii promoted himself on YouTube and the Internet. A seminary dropout, he portrayed himself as a hesychastic master. Although theoretically initiated into the deepest level of ascetic practice - the schema- he did not step away from administration of monastery property. When in January 2020, he decided to rebel against both patriarch and president, he made himself vulnerable to retaliation and removal from his convent by the authorities; only in December, nearly twelve months later, was he finally arrested.

Both church and state were clearly reluctant to take forceful action against Sergii, for the errant monk's struggles to define himself reflect the broader struggles of the post-Soviet church to define its own identity and role. For nearly two decades, the Russian Orthodox Church hierarchy embraced Sergii. In churchproduced films, such as The Dwelling Place of Faith and Love (2014), prominent clergy publicly celebrated Sergii's spiritual gifts and leadership. His organizational abilities apparently proved invaluable as the Russian Orthodox Church developed a series of monastic complexes memorializing the royal family and the lost Christian empire that they once led. Both Sergii and the church 
required a narrative to link pre-revolutionary Russia with the post-Soviet present. In his accounts of his initiation into the religious life, Sergii took pains to make such a personal connection with the holy Russia of the Romanovs. Drawing from narratives that were already circulating among right-wing Orthodox believers, Sergii also selected stories that emphasized Russia's unique eschatological role in the world (for example, as the defender of the traditional family and heteronormative sexual morality). Orthodox traditionalists, such as the Ekaterinburg bishop, Metropolitan Kirill (Nakonechnyi), supported and sympathized with this aspect of Sergii's moral campaign.

However, Sergii went far beyond Kirill's capacity for tolerance when he styled Stalin as a secret defender of Orthodoxy. This legend of the pious Stalin, fashioned in the 1990s, was especially useful to post-Soviet believers nostalgic both for pre-revolutionary holy Russia and for Stalin's industrial and military achievements. By treating the novelist Aleksandr Trapeznikov's fictional testament as a genuine historical document, Sergii simply denied the conflict between Stalin and his tsarist predecessors and tried to eliminate the cognitive dissonance of the twenty-first-century Christian who venerated Nicholas II and celebrated Joseph Stalin. Sergii's vision of holy Russia reconciled the Soviet and imperial pasts - but at the cost of forgetting Stalin's victims. In his open letter of July 2020 to Sergii, Kirill—who years earlier had praised the monk for his spiritual acumen-sharply criticized him for ignoring the martyrs who had suffered at Stalin's hands [Kirill 2020].

Sergii's remarkable rise and fall as an abbot illustrates both the power and limits of the narratives that he wielded in his cause. For a time, he was able to perform the role of spiritual elder and to gain the support of his ecclesiastical superiors and fellow clerics. The more difficult task of finding an acceptable and authoritative narrative that could satisfactorily reconcile the sharp contradictions between Stalinist and imperial Russia eluded him. The crisis of the pandemic heightened, but did not create, the tensions that already existed in his ministry. These tensions exist in the broader church as well, which both celebrates the Stalinist victory in the Great Patriotic War and commemorates Stalin's victims in the canonizations of new martyrs.

\section{NOTES}

1 Lincoln uses the term myth to describe texts that folklorists would classify as legends. I have retained that term in the discussion of his approach but will use legend hereafter.

2 The seventeenth-century Church of St. Nicholas, which functions as both museum and place of worship, contains several of the holiest works of art in the Tretyakov collection. This arrangement, worked out in the 1990s, allows the museum specialists to preserve the art in their care even as these holy objects remain in a consecrated space where believers can use them in worship. 


\section{BIBLIOGRAPHY}

66.ru. 2020a. “Отец Сергий указан священником на сайте Ташкентской епархии. Он избежит церковного суда на Урале?" [Father Sergii Is Listed as a Priest on the Site of the Tashkent Diocese. Will He Escape the Church Court in the Urals?], 66.ru, 10 June. Cited by https://66.ru/news/society/231631/ (consulted 29 April 2021).

66.ru. 2020b. “Экс-глава свердловского ГУФСИН Иван Жарков обвинил митрополита Кирилла во лжи о прошлом схиигумена Сергия" [Ivan Zharkov, the Former Head of the Sverdlovsk Main Administration of the Federal Service for Carrying Out Punishment, Has Accused Metropolitan Kirill of Lying about Schema-abbot Sergii], 66.ru, 20 July. Cited by https://66.ru/news/society/232608/ (consulted 29 April 2021).

Abramova, O. S and G. Iu. Zaitseva. 2003. Абрамова, О. С. and Г. Ю. Зайцева "Масонство в России. Масоны на страницах романа Л. Н. Толстого Война и мир" [Freemasonry in Russia. Masons on the Pages of L. N. Tolstoy's War and Peace], Русская словесность 1 (January): 32-35.

Ageeva, Е. А. 1997. Агеева, Е. А. "Старообрядческая полемика об антихристе на исходе XX века" [Old Believer Polemics about the Antichrist at the End of the Twentieth Century], в Уральский сборник. История, культура, религия. Екатеринбург : Изд-во Урал. госун-та, 916.

Agenstvo Agrofakt. 2005. Агенство Агрофакт. "Свердловская область: женский монастырь отлучил фермеров от света и воды” [Sverdlovskaia Oblast': A Convent Separates Farmers from Light and Water], Крестьянские ведомости, 18 October.

Akhmetova, M. V. 2011. Ахметова, М. В. Конеи света в одной отдельно взятой стране: Религиозные сообщества постсоветской России и их эсхатологический миф [The End of the World in One Country Taken Separately: Religious Societies of Post-Soviet Russia and Their Eschatological Myth]. Москва: ОГИ.

Allred, Louis R. 1982. Treasures of Knowledge: Selected Discourses and Excerpts from Talks by Rulon C. Allred. Vol. 2. Hamilton, Montana: The Bitterroot Publishing Company.

Andreev, Oleg and Vadim Novinskii. 2016. Андреев, Олег and Вадим Новинский "Консервативный политик" [A Conservative Politician], Корреспондент 33 (2 September): 12-16. Cited by https://novynskyi.com/ru/news-statements/konservativnyy-politik/. (consulted 29 April 2021).

Antonenkov, Dmitrii. 2020. Антоненков, Дмитрий. “Чем живут и к чему готовятся последователи схиигумена Сергия в тайных таежных убежищах. Экспедиция 66.RU" [How Do the Followers of Schema-abbot Sergii Live and What Are They Preparing for in Their Secret Refuges in the Taiga? A 66.RU Expedition], 66.ru, 18 June. Cited by https://66.ru/news/society/231741/. (consulted 29 April 2021). 
Aliev, Sergii (Ruslan). 2014. Алиев, Сергий (Руслан). Духовник [Confessor]. Екатеринбург: Первый Международный Позитивный Информационный Портал. YouTube. Cited by https://youtu.be/f1tKZEVSL8. (consulted 8 May 2021).

Baranchik, Iurii. 2014. Баранчик, Юрий. “«Окно Овертона». Как работают информационные технологии по дегуманизации человека и общества" [The "Overton Window": How Information Technologies Work for the Dehumanization of People and Society], Столетие, 23 March. Cited by http://www.stoletie.ru/versia/_okno_overtona 603.htm. (consulted 29 April 2021).

Byford, Jovan. 2011. Conspiracy Theories. London: Palgrave Macmillan.

Campion-Vincent, Véronique. 2005. "From Evil Others to Evil Elites: A Dominant Pattern in Conspiracy Theories Today," in Rumor Mills: The Social Impact of Rumor and Legend, Gary Alan Fine, Véronique CampionVincent, and Heath Chip, eds., New Brunswick, NJ: AldineTransaction, 103-122.

DeHaven-Smith, Lance. 2013. Conspiracy Theory in America. Austin: University of Texas Press.

Douglas, Karen M., Robbie M. Sutton, and Aleksandra Cichocka. 2017. "The Psychology of Conspiracy Theories," Current Directions in Psychological Science 26(6): 538-542.

Dvorianskov, I. V. 2018. Дворянсков, И. В. Роль библиотек исправительных учреждений в организаиии воспитательной работы с осужденными: практическое руководство [The Role of Libraries of Correctional Institutions in the Organization of Educational Work with Convicts: A Practical Guide]. Вологда: Вологодский институт права и экономики.

E1.ru. 2020. “'Ему 20 лет нельзя было рукополагаться': священник — о том, как начинал служить скандальный отец Сергий” [“"He Should Not Have Been Ordained for Twenty Years': A Priest Speaks about How the Scandalous Father Sergii Began to Serve"], E1.ru, 1 August. Cited by https://www.e1.ru/news/spool/news id-69398422.html. (consulted 29 April 2021).

Ebenezer Baptist Church. 1975. "How Near the End?," Wilkes-Barre TimesLeader, the Evening News, Wilkes-Barre Record, 18 October: 10. Cited by https://www.newspapers.com/newspage/407095089/. (consulted 29 April 2021).

Fenster, Mark. 1999. Conspiracy Theories: Secrecy and Power in American Culture. Minneapolis: University of Minnesota Press.

Galeotti, Mark. 2018. The Vory: Russia's Super Mafia. New Haven: Yale University Press.

Golunov, Serghei and Vera Smirnova. 2015. "Proliferation of Conspiracy Narratives in Post- Soviet Russia: The "Dulles' Plan" in Social and Political Discourses." Acta Slavica Iaponica 37: 21-45.

Gordon, Michael R. 1999. "Russian Priests Accuse a Bishop, Plunging the Church into Turmoil." The New York Times, 18 July: 1. 
Gulagu.net. 2017. "Красная утка": как коррупционеры сидят в ИК-13 Нижнего Тагила" [The "Red Duck": How Corrupt People Serve Time in Corrective Colony 13 of Nizhnii Tagil], Gulagu.net, 3 December. (consulted 5 January 2021).

Gusakov, Andrei. 2019. Гусаков, Андрей. "Технология, которая вас шокирует, но поможет сдвинуть с места мертвые продажи" [Technology that Shocks You, but Helps Get Dead Sales Moving], Коммерческий директор 1(93) (January): 22-32. Cited by https://e.komdir.ru/692788. (consulted 29 April 2021).

Husting, Ginna and Martin Orr. 2007. "Dangerous Machinery: 'Conspiracy Theorist' as a Transpersonal Strategy of Exclusion," Symbolic Interaction 30(2) (Spring): 127-50.

Il'ina, Raisa Nikolaevna. 2013. Ильина, Раиса Николаевна "Обращение Министру социальной политики Андрею Владимировичу Злоказову” [Appeal to Andrei Vladimirovich Zlokazov, the Minister of Social Policy], Русский вестник, 20 July. Cited by http://www.rv.ru/content.php3?id=10256. (consulted 29 April 2021).

Il'inskii, Igor' Mikhailovich. 2009. Ильинский, Игорь Михайлович. Образование, Молодежь, Человек: (статьи, интервью, выступления): Кн. 2 [Education, Youth, Person: Articles, Interviews, Speeches]. Москва: Изд-во МосГУ.

Ivanov, Anatolii Stepanovich. 1976. Иванов, Анатолий Степанович. "Вечный зов: роман, кн.2" [The Eternal Call: A Novel, book 2]. Москва 9 (September): $38-51$

JustMedia.ru. 2018. “«Правила жизни» схиигумена Сергия (Романова)” [Schema-abbot Sergii (Romanov)'s Rules of Life], JustMedia, 6 March. Cited

by http://www.justmedia.ru/analitika/society/pravila zhizni shiigumena sergi ya romanova. (consulted 29 April 2021).

Karamzin, Vitalii. 2020. Карамзин, Виталий. “Тайны отсидевшего за убийство схимонаха Сергия" [The Secrets of Schema-monk Sergii, Who Served Prison Time for Murder], vesti.ru, 8 August. Cited by https://www.vesti.ru/article/2438130. (consulted 29 April 2021).

Kirill (Nakonechnyi). 2020. Кирилл (Наконечный), Митрополит Екатеринбургский и Верхотурский. "Правящий архиерей направил открытое письмо схимонаху Сергию (Романову)" [The Ruling Bishop Has Sent an Open Letter to Schema-monk Sergii (Romanov)]. Екатеринбургская епархия, 6 July. Cited by http://www.ekaterinburgeparhia.ru/news/2020/07/06/23515/. (consulted 29 April 2021).

Kolezev, Dmitrii. 2020. Колезев, Дмитрий. “ «Не является штатным клириком» Как екатеринбургская епархия комментирует слова «духовника Поклонской» о двойниках Путина" [“He Is Not a Regular Cleric": How the Ekaterinburg Diocese Is Commenting on the Words of "Poklonskaia's Confessor" about Putin's Double], Znak.com, 22 January. Cited by https://www.znak.com/2020-01- 
22/ekaterinburgskaya_eparhiya_ne_kommentiruet_slova_duhovnika_poklo nskoy_o_dvoynikah_putina. (consulted 29 April 2021).

Komarova, Anastasiia. 2020. Комарова, Анастасия. "Коронавирус. Хроника распространения" [The Coronavirus: A Chronology of Its Dissemination], Российская газета, 30 March. Cited by https://rg.ru/2020/03/03/koronavirus-hronika-rasprostraneniia.html. (consulted 29 April 2021).

Komova, Marianna Aleksandrovna. 2006. Комова, Марианна Александровна. "Иконное наследие Орловского края XVIII-XIX веков" [The Icon Heritage of the Orlovskii Region in the 18th and 19th Centuries]. Kandidat iskusstvodeniia diss., Москва : МГУ. Cited by https://dlib.rsl.ru/viewer/01002975589. (consulted 29 April 2021).

Korsakov, Konstantin Viktorovich. 2017. Корсаков, Константин Викторович. "Криминологический и уголовно-правовой анализ современной организованной преступности" [A Criminological and Legal Analysis of Contemporary Organized Crime], Научный ежегодник Института философии и права Уральского отделения Российской Академии наук 17(3): $67-84$.

Legenda 2020. 2020. Легенда 2020. Билл Гейтс представил план чипизаџии всех людей на планете [Bill Gates Has Presented a Plan to Microchip Everyone on the Planet]. YouTube. Cited by https://www.youtube.com/watch?v=BXu LhXrPmk. (consulted 29 April 2021).

Lenta.ru. 2018. “Духовник Поклонской изгнал бесов на видео” [Poklonskaia's Confessor Exorcized Demons on Video], Lenta.ru. March 6, 2018. Cited by https://lenta.ru/news/2018/03/06/izgnaniye/. (consulted 29 April 2021).

Lincoln, Bruce. 1999. Theorizing Myth: Narrative, Ideology, and Scholarship. Chicago: University of Chicago Press.

Lincoln, Bruce. 2014. Discourse and the Construction of Society: Comparative Studies of Myth, Ritual, and Classification. $2^{\text {nd }}$ edition. New York: Oxford University Press.

Lonsky, Jakub. 2020. "Gulags, Crime, and Elite Violence: Origins and Consequences of the Russian Mafia," BOFIT Discussion Papers 24: 1-57. Cited by https://helda.helsinki.fi/bof/handle/123456789/17712. (consulted 29 April 2021).

Luchenko, Kseniia. 2020. Лученко, Ксения. "Широко закрытые двери. Что случилось с русской церковью во время пандемии" [Widely Closed Doors: What Happened with the Russian Church during the Pandemic], Carnegie Moscow Center, 30 April. Cited by https://carnegie.ru/commentary/81681. (consulted 29 April 2021).

Luk'ianov, Alexander. 2020. Лукьянов, Александр. Схиигумен Сергий. Последнее слово [Schema-abbot Sergii. The Last Word]. YouTube. Cited by https://www.youtube.com/watch?v=btFe5-4BTm8. (consulted 29 April 2021). 
Mackinac Center. 2019. "The Overton Window." Cited by http://www.mackinac.org/OvertonWindow. (consulted 29 April 2021).

Malinowski, Bronislaw. 1926. Myth in Primitive Psychology. London: Kegan Paul, Trench, Trubner and Company.

Martem'ianov, Maksim. 2020. Мартемьянов, Максим. “Сердце русской тьмы-2: отец Сергий забивает до смерти” [The Heart of Russian Darkness - 2: Father Sergii Beats People to Death]. Батенька, да вь трансформер, 14 July. Cited by https://batenka.ru/worship/dictator/heartof-russian-darkness-2/. (consulted 29 April 2021).

Murov, Evgenii. 2000. Муров, Евгений. "У охраны президента нет права на ошибку" [The Presidential Guard Has No Right to Make a Mistake], Комсомольская правда 141 (8 April): 4.

Musser, Joe. 2011. "Remembering a Life... Rev. David Wilkerson." 29 April. Cited by https://joemusserco.livejournal.com/11021.html. (consulted 29 April 2021).

Novaia gazeta. 2021. Новая газета. “Приставы прибыли в Среднеуральский женский монастырь с решением о выселении жителей” [Marshals Arrived in Sredneural'skii Convent with a Judgment to Evict the Residents], Новая газета, 13 April. Cited by https://novayagazeta.ru/articles/2021/04/14/pristavy-pribyli-vsredneuralskii-zhenskii-monastyr-s-resheniem-o-vyselenii-zhitelei. (consulted 4 May 2021).

Orthodox Church of Moldova. 2020. "Adresare. Privind Legalitatea Unei Eventuale Vaccinari Obligatorii ca Efect al Virusului SARS-COVID-19" [An Address on the Legality of a Possible Mandatory Vaccine as a Result of the SARS-COVID-19 Virus], 19 May. Cited by https://mitropolia.md/wpcontent/uploads/2020/05/Adresare-Covid-1.docx. (consulted 1 May 2021).

Osipov, Vladimir Nikolaevich. 2000. Осипов, Владимир, “Карточка для ЦРУ и антихриста." [A Card for the CIA and the Antichrist], Независимая zазета, 22 March. Cited by http://www.ng.ru/facts/2000-0322/6 chipcard.html. (consulted 29 April 2021).

Ostapov, Aleksei. 2013. Остапов, Алексей. “Рейдерство именем божьим. РПЦ выживает с земли свердловских фермеров" [Raiding in the Name of God. The Russian Orthodox Church Lives Off the Land of Sverdlovsk Farmers], Вечерние ведомости, 4 October. Cited by https://veved.ru/eburg/press/38255-rejderstvo-imenem-bozhim-rpcvyzhivaet-s-zemli-sverdlovskix-fermerov.html. (consulted 29 April 2021)

Ostapov, Aleksei. 2014. "Екатеринбургских святых отцов уличили в покровительстве священнику-убийце" [The Holy Fathers of Ekaterinburg Have Been Caught Protecting a Priest-Murderer]. Правды УРФО, 19 February. Cited by https://pravdaurfo.ru/articles/ekaterinburgskih-svyatyhotcov-ulichili-v-pokrovitelstve-svyashchenniku-ubiyce. (consulted 29 April 2021).

Panchenko, Aleksandr A. 2015. Панченко, Александр А. “Компьютер по имени Зверь: эсхатология и конспирология в современных 
религиозных культурах" [The Computer Named Beast: Eschatology and Conspirology in Contemporary Religious Cultures], Антропологический форум 27: 122-140.

Panchenko, Aleksandr A. 2017. "The Beast Computer in Brussels: Religion, Conspiracy Theories, and Contemporary Legends in Post-Soviet Culture," Folklore: Electronic Journal of Folklore 69: 69-90. Cited by https://www.folklore.ee/folklore/vol69/panchenko.pdf. (consulted 29 April 2021).

Panchenko, Aleksandr A. 2018. Панченко, Александр А. ““План Даллеса': Советская литература, теории заговора и моральные паники в России рубежа XX и XXI веков" [The Dulles Plan': Soviet Literature, Conspiracy Theories, and Moral Panics in Russia at the Edge of the XX and XXI Centuries], Русская литература 2: 118-136.

Papkova, Irina. 2011. The Orthodox Church and Russian Politics. Washington

D.C: Woodrow Wilson Center Press.

Parents for Healthcare Rights. 2020. Italian Politician Sara Cunial Accuses Bill

Gates and the Corrupt Parliament. YouTube. Cited by https://www.youtube.com/watch?v=2NGMJDz7MFs. (consulted 8 May 2021).

Petrov, Eduard. 2018. Петров, Эдуард. Former Law Enforcement Officers in the Colony. Расследование Эдуарда Петрова. 22 November. YouTube. Cited by https://www.youtube.com/watch?v=on G6u0L94Y. (consulted 29 April 2021).

Popper, Karl R. 2013. The Open Society and Its Enemies. Alan Ryan and E. H. Gombrich, eds. Princeton: Princeton University Press.

Pushkarev, Igor'. 2015а. Пушкарев, Игорь. “Свердловский фермер, который 13 лет борется с РПЦ за свои земли, приглянувшиеся духовнику Поклонской, выиграл очередной суд" [A Sverdlovsk Farmer, Who Fought with the Russian Orthodox Church for His Lands that Poklonskaia's Confessor Wanted, Has Won the Next Suit], Znak.com, 19 June. Cited by https://www.znak.com/2015-06-

19/sverdlovskiy fermer kotoryy 13 let boretsya s rpc za svoi zemli p riglyanuvshiesya duhovniku poklonsk. (consulted 29 April 2021).

Pushkarev, Igor’. 2015b. “«Это желание самой Натальи Поклонской» Рейдерский захват, монах с криминальным прошлым и покойный вор в законе" ["That's the Wish of Natal'ia Poklonskaia Herself": A Hostile Takeover, a Monk with a Criminal Past, and a Dead Thief with a Code of Honor], Znak.com, 2 June. Cited by https://www.znak.com/2015-0602/reyderskiy zahvat monah s kriminalnym proshlym i pokoynyy vor V zakone chto svyazyvaet prokurora kry. (consulted 8 May 2021).

Pushkarev, Igor'. 2020. “«Романов в секунду перевернулся и начал буквально орать на них». Православная журналистка, расследовавшая деятельность схиигумена Сергия, рассказала Znak.com его историю" ["Romanov in a Second Turned around and Began Literally to Roar at Them": The Orthodox Journalist Investigating Schema-monk Sergii's 
Activities Has Recounted Her Story to Znak.com], Znak.com, 25 June. Cited by https://www.znak.com/2020-06-

25/pravoslavnaya zhurnalistka rassledovavshaya deyatelnost shiigumena sergiya_rasskazala_znak_com_ego_i. (consulted 29 April 2021).

Pushkarev, Igor' and Mariia Pliusina. 2020. Пушкарев, Игорь and Мария Плюсина. “«В пределах Свердловской области возникает своеобразный Ватикан»" [A Peculiar Vatican Arises in Sverdlovskaia Oblast'], Znak.com, 16 June. Cited by https://www.znak.com/2020-0616/bolee $1 \mathrm{mln} \mathrm{kv} \mathrm{m}$ bolshinstvo zemel i monastyrey otca sergiya o kazalis ne oformlennymi . (consulted 29 April 2021).

Relfe, Mary S. 1981. When Your Money Fails: The 666 System Is Here. Montgomery: Ministries, Inc. Cited by https://archive.org/details/whenyourmoneyfai00relf.(consulted 29 April 2021).

Sedmitsa.RU. 2010. Седмица.RU “Летопись мужского монастыря в честь святых Царственных Страстотерпцев на Ганиной яме” [Chronicle of the Holy Royal Passion-bearers Monastery in Gania's Pit], Седмица.RU: Церковно-Научный Центр “Православная Энциклопедия," 18 Мау. Cited by https://www.sedmitza.ru/text/1160694.html. (consulted 1 May 2021).

Sergii (Romanov). 2020. Сергий (Романов). Проповедь схиигумена Сергия (Романова) от 06.01.2020. Путин, ложь и правда о Сталине [Sermon of Schema-abbot Sergii (Romanov) of 6 January 2020: Putin, Falsehood and Truth about Stalin]. Cited by https://t.me/SergyRomanov/5. (consulted 1 May 2021).

Shestak, Ivan. 2020. Шестак, Иван. “Схиигумен Сергий рассказал, как отбывал срок за убийство, а потом стал священником” [Schema-abbot Sergii Recounted How He Served a Prison Term for Murder and Then Became a Priest], E1.ru, June 22. Cited by https://www.e1.ru/news/spool/news_id-69328702.html. (consulted 1 May 2021).

Sinod. 1999. Священный Синод Русской Православной Церкви. “Определения Священного Синода от 4 июня и 18-19 июля 1999 года.” [Decisions of the Holy Synod from 4 June and 18-19 July 1999], Патриархия.ги. Официальный сайт Московского Патриархата. Cited by http://www.patriarchia.ru/db/text/4948013.html. (consulted 1 May 2021).

Sinod. 2005. Священный Синод Русской Православной Церкви. “Журналы заседания Священного Синода Русской Православной Церкви от 20 апреля 2005 года" [Minutes of the Meeting of the Holy Synod of the Russian Orthodox Church on 20 April 2005], Патриархия.ru. Официальный сайт Московского Патриархата, April. Cited by http://www.patriarchia.ru/db/text/1496072.html. (consulted 1 May 2021). 
Skoblikov, Evgenii Andreevich. 2016. Скобликов, Евгений Андреевич. Революиия отменяется. Третий путь развития [The Revolution Has Been Canceled. A Third Way of Development]. Санкт-Петербург: Весь.

Skoibeda, Ul'iana. 2017. Скойбеда, Ульяна. “Люди, долго работавшие с Натальей Поклонской: Она у нас неистовая во всем” [People Who Have Long Worked with Natal'ia Poklonskaia: In Everything, She Is Fierce], Комсомольская правда, 21 October: 8-12. Cited by https://www.kp.ru/daily/26747.7/3775856/. (consulted 2 May 2021).

Smirnov, Sergei. 2013. Смирнов, Сергей. "Монах в законе” [A Monk with a Code of Honor]. $M K$ - Урал, 25 December. Cited by https://eburg.mk.ru/article/2013/12/25/964855-monah-v-zakone.html.

(consulted 2 May 2021).

Smirnov, Aleksei. 2017. Смирнов, Алексей. “«Красная Утка»: где и как сидят «оборотни в погонах»" [The "Red Duck": Where and How "Werewolves in Uniform" Serve Time], АиФ Урал, 29 November. Cited by https://ural.aif.ru/society/krasnaya utka gde kak i za chto motayut srok na urale oborotni $\mathrm{v}$ pogonah. (consulted 30 April 2021).

Soboleva, L. S. 1997. “Американское сочинение об Антихристе-компьютере в интерпретации уральского старовера" [An American Essay about the Antichrist-computer in the Interpretation of a Ural Old Believer], в Исследования по истории книжной и традиционной народной культуры Севера: Межвузовский сборник научных трудов. Т. Ф. Волкова, ed. Сыктывкар: Сыктывкарский ун-т, 118-30.

Srednii put'. 2020. Средний путь. 75 Лет Великой Победы - Поздравление с Днем Победы из Среднеуральского женского монастыря [Seventy-five Years Since the Great Victory: Happy Victory Day from Sredneural'sk Convent]. 23 April. Cited by https://www.youtube.com/watch?v=PeF00t7HK7w. (consulted 29 April 2021).

Stalin, Joseph. [Trapeznikov, Aleksandr]. Сталин, Иосиф [Трапезников, Александр] 2004. “Завещание Сталина (Фрагменты черновика)." [Stalin's Testament: Fragments of a Draft], Родная Сибирь 4 (August). Cited by http://cont.ws/uploads/pic/2017/1/zaveshanie_stalina.jpg. (consulted 29 April 2021).

Stoianov, Evgenii. 2020. Стоянов, Евгений. “«С чего мы стали сектой?»: послушники - об опальном отце Сергие, захватившем Среднеуральский женский монастырь” [“Since When Did We Become a Sect?" Novices on the Disgraced Father Sergii, Who Seized Sredneural'skii Convent], ural.kp.ru, 17 June. Cited by https://www.ural.kp.ru/daily/27144/4237804/. (consulted 29 April 2021).

Stojanov, Ana, Jesse M. Bering, and Jamin Halberstadt. 2020. "Does Perceived Lack of Control Lead to Conspiracy Theory Beliefs? Findings from an Online MTurk Sample," Gaëtan Merlhiot, ed., PLOS ONE 15 (8): 1-18. Cited 
https://journals.plos.org/plosone/article?id=10.1371/journal.pone.0237771. (consulted 29 April 2021).

Tangherlini, Timothy, Vwani Roychowdhury, and Peter Broadwell. 2020. "Bridges, Sex Slaves, Tweets, and Guns: A Multi-Domain Model of Conspiracy Theory," in Folklore and Social Media. Andrew Peck and Trevor J. Blank, eds. Logan: Utah State University Press, 39-66.

Telestudiia Ekaterinburgskoi eparkhii. 2013. Телестудия Екатеринбургской епархии. Обитель веры и любви. [A Dwelling Place of Faith and Love]. Cited by https://www.youtube.com/watch?v=Vn-PGultvI0. (consulted 1 May 2021).

Trapeznikov, Aleksandr. 1997a. Трапезников, Александр. Завещзание красного монарха [Last Will and Testament of a Red Monarch]. Москва: Палея.

Trapeznikov, Aleksandr. 1997b. Трапезников, Александр. “Завещание красного монарха" [Last Will and Testament of a Red Monarch], Завтра 50(211), 16 December.

Uscinski, Joseph E., ed. 2018. Conspiracy Theories and the People Who Believe Them. New York: Oxford University Press.

Varese, Federico. 2001. The Russian Mafia: Private Protection in a New Market Economy. Oxford: University Press.

Vaulin, Paul. 1981. Ваулин, Павел. “Наступление зверя” [Advent of the Beast], Нива 9 (September): 3-6.

Wilkerson, David. 1972. The Rapture. David Wilkerson Youth Crusades.

Wilkerson, David. 1973. Signs of the Times. Dallas, TX: David Wilkerson Publications.

Worobec, Christine. 2001. Possessed: Women, Witches, and Demons in Imperial Russia. DeKalb, IL: Northern Illinois University Press.

Zhadaev, Ivan. 2020. Жадаев, Иван. "Красное и черное: две стороны российской исправительной системы" [Red and Black: Two Sides of the Russian Correctional System], МБХ медиа, 15 July. Cited by https://mbknews.appspot.com/suzhet/krasnoe-i-chernoe-dve/. (consulted 1 May 2021).

Zharkov, Ivan Danilovich. 2020. Жарков, Иван Данилович. “Экс-глава свердловской ГУФСИН заступился за опального отца Сергия" [The Former Head of the Sverdlovsk Main Administration of the Federal Service for Carrying out Punishment Has Interceded for the Fallen Father Sergii]. 19 July. Cited by https://www.ural.kp.ru/video/791414/. (consulted 29 April 2021).

Zhogolev, Anton. 2009. Жоголев, Антон. “Царский салют” [Tsarist Salute], Благовест, 3 September. Cited by http://xn--80aaaabhgr4cps3ajao.xn-p1ai/-public page 8483. (consulted 29 April 2021). 